\title{
LA IDENTIDAD LITERARIA DE MANUEL ALTOLAGUIRRE: EVOLUCIÓN DE UNA TEORÍA POÉTICA
}

\author{
Susana Arroyo Redondo \\ Universidad de Alcalá de Henares
}

\section{Presentación}

Al repasar el censo de los protagonistas de la historia de la literatura, se descubre una selección caprichosa que suele depender de los gustos de la época, de las preferencias de los críticos o de factores puramente extraliterarios. Manuel Altolaguirre es uno de los maltratados por la historia de la literatura. Fue vecino de la Residencia de Estudiantes, íntimo amigo de todos los miembros de su generación, poeta comprometido durante la guerra, exiliado, editor de revistas como Litoral, Héroe, 1616 o Caballo verde para la poesía, traductor, dramaturgo, guionista y director de cine, sin que en cada una de estas facetas haya recibido todavía la atención merecida.

Efectivamente, su obra poética es poco conocida y apenas ha obtenido el interés de ciertos críticos como Cernuda, Martí Soler, Margarita Smerdou Altolaguirre y Milagros Arizmendi, quienes han publicado sus versos en ediciones críticas. Peor suerte habían corrido sus numerosas crónicas y artículos de crítica literaria, que permanecieron inéditos y dispersos hasta 1986 cuando fueron finalmente recopilados por James Valender en una edición completa'.

El olvido que ha sufrido la obra del malagueño se debe en primer lugar al hecho de que los estudios sobre la Generación del 27 se siguen centrando en ciertos autores ya consagrados, como Lorca, Cernuda o Dámaso, mientras que otras voces menos conocidas, como las de Bergamín, Prados o el propio Altolaguirre, parecen eternamente relegadas a un apartado de figuras menores

1.- Obras Completas, I-III, ed. de James Valender, Madrid, Istmo, 1986. Para acercarse a su figura también se pueden consultar las páginas que le dedicó Luis Cernuda en sus Estudios sobre poesía española contemporánea (Barcelona, Guadarrama, 1970), la obra de John Crispin, Quest for wholeness: the personality and works of Miguel Altolaguirre (Valencia, Albatros, 1983) o la biografía escrita por Gonzalo Santonja, Un poeta español en Cuba, Miguel Altolaguirre: sueños y realidades del primer impresor del exilio (Barcelona, Galaxia Gutemberg, 1996). 


\section{LA IDENTIDAD LITERARIA DE MANUEL ALTOLAGUIRRE}

del grupo en el que nadie ha intentado profundizar. En segundo lugar, el afán que tuvo el malagueño por publicar la obra de sus compañeros ${ }^{2}$ es comparable a su escaso celo por reunir sus textos de crítica literaria en un solo volumen, lo que provocó que la mayoría de sus ensayos quedaran inéditos o aparecieran dispersos en numerosas revistas de los diferentes países en que sufrió su errático exilio.

Ante semejante panorama se comprenderá que la figura de Altolaguirre permanezca todavía ajena para buena parte de la crítica y el público en general. Este artículo pretende elucidar ciertos aspectos de la identidad poética del malagueño en su faceta más desconocida, la de crítico literario. Concretamente, se intentarán exponer las claves de su sólida teoría poética a partir de sus copiosos artículos y ensayos literarios.

Para ello se ha dividido este estudio en dos partes; primero se expondrá la personal concepción de poesía que Altolaguirre desarrolló; luego se indagará sobre su visión de la figura del poeta. Y aunque este sucinto trabajo no haya podido recoger todos los aspectos del complejo programa crítico del malagueño, la fuerte coherencia de su teoría literaria sí ha hecho posible reconstruir las principales líneas de su pensamiento.

\section{Poesía}

La primera cualidad que se debe anticipar sobre la identidad poética de Manuel Altolaguirre es que, para él, el objeto poético es abstracto e inasible, apenas un estímulo de conocimiento que funde al lector con toda la humanidad; una realidad que espera ser recordada por un poeta. Es un ente que se ha tratado de definir en multitud de ocasiones y con muchas fórmulas, pero que nunca quedó aprisionado en una palabra u oración. Y en efecto, el poeta malagueño era muy consciente de que el concepto de poesía era inefable; por eso las definiciones que esbozará en sus escritos son bastante inciertas e incluso herméticas a pesar de su voluntad universal.

\section{1. Origen}

A lo largo de la historia de la literatura, uno de los tópicos más recurrentes y polémicos sobre la creación literaria es el del origen de la inspiración. Generalizando se puede decir que cierta corriente ha considerado que un poema es el resultado de la aplicación de diversas técnicas de composición, de una labor consciente y voluntaria; se hablaría entonces de una "ciencia poética". Para otra tendencia, los poetas poseen un genio innato, imbuido por Dios o por la Naturaleza, que permitirá distinguir la mejor poesía de aquella que sólo sigue una normativa; es el llamado "furor poético" o "manía poética". Esta disputa, surgida de la filosofía griega, ha sido fundamental en la historia de la crítica literaria.

A principios del siglo XX, durante la juventud de Altolaguirre y debido a la influencia de las vanguardias, se extendió la idea de que el poeta era un trabajador más que gracias a la dedicación podía crear poemas sin que la inspiración interviniera en ningún momento.

Sin embargo, el malagueño siempre permaneció alcjado de esta interpretación mecanicista de la creación poética y se decantó por la segunda opción arriba señalada, aunque con importantes matices. Así, comparte con esta corriente de pensamiento el rechazo a la idea de poesía como un producto manufacturado pero la supera al considerar que el genio poético natural no es propio sólo de algunos hombres, sino de todos:

2.- Es tristemente irónico que la obra de Altolaguirre permanezca en el olvido cuando él mismo confesó que fue su trabajo como impresor el que dio a conocer a los autores más famosos de su generación: «En la imprenta Sur se publicaron los primeros romances gitanos de Federico García Lorca. Las primeras canciones de Rafael Alberti, los primeros libros de Vicente Aleixandre y de Luis Cernuda y poemas de Unamuno, Juan Ramón Jiménez, Antonio Machado, Pedro Salinas, Jorge Guillén y Gerardo Diego" ("El caballo griego", cito por sus Obras Completas I, ed. cit., p. 46). 


\title{
SUSANA ARROYO REDONIOO
}

Nada une tanto ni mejor a los hombres como el genio poético, en el que, según Blake, somos tan semejantes como en nuestra apariencia física, dentro de una infinita variedad de matices. Iguales todos los hombres para la creación y la recreación poética [...]. Poesía que del alma brota como del rostro salen las sonrisas, las señales, las lágrimas. ${ }^{3}$

Es decir, todas las personas tienen la misma capacidad poética porque ésta no depende del uso de unas técnicas precisas o de un arte aprendido. El don de la expresión poética es común a todos los seres humanos, es inherente a su naturaleza hasta el punto de unirlos y permitirles conocer el mundo:

Hablar de un poeta por lo que tiene de iniciador o de maestro es rebajarlo siempre; pues por grande que sea su originalidad de estilo, éste no ofrece, en caso de éxito, sino lo que es común a toda obra de arte: la poesía, que no puede tener discípulos ni iniciados, porque su cultivo no depende de la voluntad ni de la razón $[\ldots]^{5}$

Este es el motivo por el que Altolaguirre asegura que la poesía acerca los corazones de los hombres. La igualdad para la creación y la recreación poética es un punto en común entre los seres humanos; pues al igual que se está naturalmente capacitado para entender el amor, -la comparación de la poesía/amor será continua- también se puede captar de forma instintiva la belleza de la poesía.

Así pues, el que quiera encontrar poesía no debe registrar los caminos de la mente o la voluntad, más bien debe dejarse llevar por su propio instinto y entonces la poesía, que está en su propia naturaleza, acudirá a su encuentro:

Cuya gracia [la de la poesía] no es privilegio del estudioso, sino más bien del distraído, ya que el mayor caudal lírico discurre siempre en el campo de lo popular, navega las aguas de la niñez, cruza las nubes del sucño, ${ }^{6}$

Este último pasaje es especialmente importante porque recoge los tres caminos por los que Altolaguirre buscó siempre la inspiración poética: la verdadera vida, la inocencia y la intimidad de los sueños. Su poesía, bajo la influencia de Juan Ramón Jiménez y Garcilaso, siempre rechazó cualquier afectación y frivolidad. El acto poético era concebido como una manifestación de la personalidad y un descubrimiento de lo que se esconde en los sueños.

Por todo esto, el acto poético no requiere ningún tipo de erudición, ya que «el poeta no hace depender lo que escribe de circunstancias ni de efectos exteriores» ${ }^{7}$, se sirve de su propia experiencia vital común a todos los hombres. $Y$ tampoco requiere ninguna intencionalidad, pues la expresión poética es alma que fluye en la naturaleza del ser humano.

Todas estas ideas tienen su lugar en la identidad poética de Manuel Altolaguirre y se manifiestan claramente en su obra. Así, se pueden encontrar poemas que descubren su visión del hombre como un ser dotado naturalmente con la gracia poética:

\author{
[...] Escribir es nacer \\ dejar la cristalina
}

\footnotetext{
3.- "En el campo de la poesía clásica española", Universidad de la Habana, 48 (mayo-junio 1943), pp.123-128. Cito por Obras Completas I, ed. cit., pp. 275-280, cita en p. 277.

4.- En este apartado de la teoría poética de $A$ ltolaguirre se puede reconocer fácilmente la influencia de su maestro Juan Ramón Jiménez quien ya había definido la poesía como una realidad natural e intuitiva: "La poesía, estado de gracia, anterior y posterior a la cultura" ("Poesía y literatura", Antolojía, Barcelona, Ediciones Orbis, 1982, pp. 283-288, cita en p. 288).

5.- "Enseñanzas de Garcilaso", Universidad de la Habana, 30-33 (mayo-diciembre 1940), pp. 174-181, cita en p. 174 .

6.- Ibidem, p. 174.

7.- "Poesía y política", Excélsior (México), 20-mayo-1949, p. 6.
} 


\title{
LA IDENTIDAD LITERARIA DE MANUEL ALTOLAGUIRRE
}

\author{
morada de inocencia \\ donde ya no estoy. \\ Mi verso tiene formas maternales, \\ es nube sobre el mar \\ y una gota de lluvia, \\ es niño que en la arena se entretiene \\ con las espumas y las caracolas. \\ Mi Padre está en los cielos \\ y yo me siento alegre, \\ nacido de su Verbo, \\ de donde salgo cada día, ${ }^{8}$
}

En este poema, Altolaguirre desarrolla la idea de que los hombres nacen del Verbo divino y precisamente Él otorga la capacidad de usar la poesía para renacer a través de clla. Todo hombre que materialice su innata capacidad poética mediante la escritura, renacerá cada día. Además, las definiciones de poesía que estos versos ofrecen - "maternal", transparente como la "nube" o una "gota de lluvia" c inocente como un "niño"- describen perfectamente los cauces por los que Altolaguirre aseguraba que cualquiera se puede encontrar, sin proponérselo, la poesía.

\section{2. Definición de poesía}

La tarea de establecer qué era la poesía para Manuel Altolaguirre no es sólo difícil sino irremediablemente fracasada. El mismo poeta no llegó a definir nunca de una manera concluyente lo que para él podría ser la sustancia poética, sino que ofreció una serie de acercamientos difusos. Pero esa inefabilidad es coherente en la identidad poética de un autor que se negó a crear una teoría cerrada sobre cualquier aspecto literario porque toda descripción de algo infinito siempre sería parcial. De hecho, la única realidad con la que la poesía aceptaría una comparación sería con la del inasible amor.

Como es fácil de imaginar, el crítico malagueño no creó tampoco ninguna preceptiva formal para la poesía. No creyó en ninguna norma exterior porque eso hubiera supuesto limitar la creación poética, que es irracional e involuntaria. Además, lo importante de un poema sería el modo misterioso en que permite conocer el mundo, y ese proceso es ajeno a lo formal.

\section{2. 1. El misterio poético}

Manuel Altolaguirre concebía la Poesía como la clave para entender el mundo y la mismidad del ser; sería un enlace entre la realidad y los hombres a través del cual se proyecta la circunstancia temporal de cada uno a un espacio abstracto poblado por ideas eternas. Según las imágenes platónicas que el poeta usó para desvelar el misterio de la poesía, las criaturas poéticas formarían un universo al que se accede por la creación o recreación poética y en el que se encuentran las verdades universales. Y todo ese grandioso mundo está formado gracias a las palabras; ellas sostienen el universo poético porque permiten crear y recrear la poesía.

Este esquema conceptual de apariencia tan hermética fue expuesto con bastante claridad en la reseña que Altolaguirre escribió sobre la obra de Luis Cernuda, La realidad y el deseo en 1936:

[...] Mundo de Belleza que vive a merced de los vocablos. Toda poesía es eso: realidades evocadas, elevación al Mundo ideal de la inteligencia de cuanto actúa sobre nuestros sentidos. ${ }^{9}$

En estas líneas queda resumido el concepto básico de lo que es la poesía: un proceso de interiorización en que, gracias a las palabras, la realidad inmediata es elevada a un mundo ideal $a$ priori inasible, pero al alcance de los futuros lectores.

8.- "Escribir es nacer" de "Poemas en América" [1955], Poesías completas, ed. de Margarita Smerdou y Milagros Arizmendi, Madrid, Cátedra, 1987, pp. 323-324.

9.- "La realidad y el deseo", Heraldo de Madrid (Madrid), 30-abril-1936, p. 4. 


\section{SUSANA ARROYO REDONDO}

Es decir, que cuando la voluntad del pocta se expresa, éste acude primero a sus vivencias o sensaciones, pues toda poesía parte de la observación de la vida. A continuación, esas realidades materiales y finitas son interiorizadas; el poeta va acumulando sentimientos y experiencias en silencio hasta que su alma se desborda súbitamente en una nueva interpretación del mundo en forma de emociones estéticas. Al fin, estas emociones se manifiestan a través de la palabra y del ritmo en un poema. Así, en esta naciente criatura poética se podrá encontrar una realidad que ya no es sólo personal porque evoca pensamientos y sentimientos comunes a todos los humanos, y por lo tanto, eternos:

Apresurado concentramiento de la realidad infinita en un pecho que como anhelosa fuente despidiera a los astros una vertical, iluminada corriente trepadora, una depurada esencia del Mundo, que a la postre no fuera sino luz que nos hiciera conocer, amar la vida. ${ }^{10}$

Por eso, la poesía sería un diálogo entre la realidad y la intimidad del poeta ${ }^{11}$ en el que se partiría de las limitadas experiencias personales de un solo hombre para crear un discurso universal, lleno de ideas atemporales:

Todo cuanto resumimos en los nombres, lo que queda de las cosas cuando nos aislamos de la realidad recordándola, es la verdadera luz que nos sirve para reconocerlas en los encuentros posteriores. ${ }^{12}$

En resumen, para el poeta es fundamental observar el mundo y luego refugiarse en la intimidad llevándose todo lo aprehendido. Lo importante de la realidad será todo aquello que luego se pueda recordar en aislamiento, es decir, aquello que precisamente está encerrado en el nombre de las cosas. Con esta nueva visión de lo real, que nada tiene que ver con lo que aprehenden los sentidos, se creará la poesía, que es un objeto de alcance universal porque ofrece un conocimiento más depurado del mundo:

\footnotetext{
Ahora sé que eres tú.

Ahora, cuando no te siento,

cuando mis sentidos no te limitan.

Ahora es cuando te tengo. ${ }^{13}$
}

La poesía -concebida como un ente casi platónico- sería un vastísimo campo formado por infinitas criaturas poéticas o poemas que han sublimado las finitas experiencias humanas. Los hombres pueden acudir a ese universo ideal poético para transformar sus conocimientos parciales sobre el mundo en otros absolutos y aprender a amar la vida.

\section{2. 2. Amor y poesía}

Y será precisamente esa relación entre conocer y amar la que lleva a Altolaguirre a definir continuamente la poesía como una forma de amor:

Iguales todos los hombres para la creación y la recreación poética, ejercicio amoroso, descanso amoroso, en el que vive nuestro ser hasta en el sueño. ${ }^{14}$

El amor es como la poesía porque son dos realidades universales que, como se verá en detalle más abajo, provocan los mismos beneficios en los hombres: les hacen conocerse a sí mismos, los liberan de lo circunstancial y les unen en fraternidad.

\section{0.- Ibídem, p. 4}

11.- Aquí de nuevo Altolaguirre sigue las consignas de Juan Ramón Jiménez sobre la naturaleza de la poesía al considerarla nexo entre la realidad y el mundo de las ideas: "L a verdadera poesía [...] es la que estando sustentada, arraigada en la realidad visible, anhela, ascendiendo, la realidad invisible; [... f fundiendo, como en el mundo total, evidencia e imajinación" ("Poesía y literatura", Antolojía, ed, cit., p. 288).

12.- "La realidad y el desco", art. cit., p. 4.

13.- "Ahora", extraída de "Poesía" [1931], Poesías Completas, ed.cit., p. 188.

14.- "En el campo de la poesía clásica española", art. cit., p. 277. 


\section{LA IDENTIDAD LITERARIA DE MANUEL ALTOLAGUIRRE}

Es decir, amor y poesía serán dos entes inseparables, pero no porque el poeta deba expresar en su poesía la intensidad de sus sentimientos, sino porque su palabra poética se creará a partir del conocimiento del mundo que proporciona el amor.

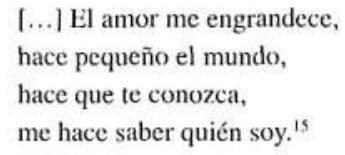

De hecho, el auténtico poeta debe ser un enamorado del mundo. Si el poeta no ama la vida, que es el material de construcción del que parte todo arte, no podrá inspirarse en ella ni tampoco beneficiarse del conocimiento que proporciona:

La poesía puede ser, como toda manifestación amorosa, un deseo y una creación, y el poeta, como todo enamorado, tiene que mirar con buenos ojos a la vida... ${ }^{16}$

Esta hermandad entre amor, poesía y vida la sintió Altolaguirre durante toda su existencia, de hecho sus poemas -excepto tal vez aquellos escritos durante la Guerra Civil- exhalan ese enamoramiento entendido como forma de vida. He aquí un bello ejemplo, aparecido en $1936 \mathrm{en}$ Las Islas Invitadas, de cómo el sentimiento amoroso impregna tanto la obra como la concepción poética del malagueño:

$$
\begin{aligned}
& \text { Recorre el amor mi verso, } \\
& \text { baja y sube por sus hilos; } \\
& \text { el corazón que lo impulsa } \\
& \text { nunca lo dejo tranquilo, } \\
& \text { que quiere vivir y late, } \\
& \text { corazón propio, escondido } \\
& \text { entre palabras que corren } \\
& \text { por venas que son suspiros. } \\
& \text { Mujer desnuda, el poema } \\
& \text { guarda su secreto ritmol......" }
\end{aligned}
$$

\section{2. 3. El provecho de la poesía}

A continuación se van a esbozar algunos de los efectos de la poesía sobre el alma humana según fueron detallados, a petición de Camilo José Cela, en una "confesión estética" que Altolaguirre escribió y que debía encabezar unos poemas suyos para una proyectada antología de los poetas de su generación.

1. 2. 3. 1. Como ya se ha indicado en estas últimas páginas, el primer cambio que produce en el alma el acercamiento a la poesía es que ofrece un conocimiento sobre el mundo y la propia personalidad que está más allá de la experiencia individual pues remite a una esfera de sentimientos y saberes comunes a todos los seres humanos:

La poesía, ya sea exterior o profunda, es mi principal fuente de conocimiento. Me enseña el mundo y en ella aprendo a conocerme a mí mismo. Por eso el poeta no tiene nunca nada nuevo que decir. La poesía es reveladora de lo que ya sabemos y olvidamos. ${ }^{18}$

15.- "Arriba", extraído de "La lenta libertad" [1936], Poesías Completas, ed. cit., pp. 223-224.

16.- "Poética", Poesía española contemporánea [1934], ed. Gerardo Diego, Madrid, Taurus, 1989, p. 509.

17.- "Secreto", extraído de "Nuevos poemas a las Islas Invitadas" [1936], Poesías Completas, ed.cit., pp. 150-151.

18.- "Confesión estética", Papeles de Son Armadans (Madrid-Palma de Mallorca), XIV, 41, (1959), p. 154. 


\section{SUSANA ARROYO REDONDO}

Altolaguirre explica que al sumergirse en un poema cuya escritura ha sido motivada por una experiencia vital o por una reflexión personal del autor, el lector trae a su memoria sus vivencias pasadas sobre el mismo hecho que serán iguales a las del poeta porque la naturaleza de todos los hombres es la misma. Esta nueva experiencia de conocimiento, que no es más que un recuerdo de algo ya olvidado ${ }^{19}$, fue comparada por el malagueño a la bella imagen de la noche interior de San Juan:

Por múltiples imágenes que de cada uno de nosotros se haya llevado el tiempo, al evocarlas en la noche interior, desde tan lejos vienen, hasta tan lejos llegan, que imposible es medir la hondura de ese doble camino, de esa herida. ${ }^{20}$

En resumen, la poesía permite conocer el mundo porque el poeta siempre se inspira en la vida, por tanto, su palabra es una recreación depurada de una realidad que se ha interiorizado. Por eso, al leer un poema se comprenderá mejor el mundo y si el lector no entiende esos versos, se estará perdiendo fragmentos de esa realidad. A este respecto, Altolaguirre especificó claramente que no hay poema incomprensible, pues todo artefacto poético es un sencillo reflejo de la vida y de la naturaleza humana, sino lectores sin la sensibilidad necesaria para recordar la experiencia o el conocimiento que esas líneas evocan:

$\mathrm{Y}$ ahora que hablamos aquí de comprensión y de amor quiero salir a la defensa de la poesía incomprendida, diciendo que ella es la que tiene que comprender, compendiar y amar al mundo que la produce. En ella está la comprensión tan incomprendida, el amor tan indiferentemente desdeñado por los hombres sin almas. ${ }^{21}$

Por otro lado, el conocimiento más importante que proporciona el mundo poético es el de uno mismo, por cuanto la poesía es una manifestación de la personalidad. Como ya se señaló antes, para Altolaguirre los hombres son semejantes dentro de una infinita variedad de matices; igual que cada forma de amar es peculiar, cada creación poética posce ciertas singularidades que reflejan lo más profundo de la personalidad del poeta. Cuando el autor habla de sí mismo en un poema, llega a un grado muy elevado de conocimiento de su propia naturaleza:

Esta actividad, esta pasividad de nuestro ánimo [la poesía], no siempre sentida ni expresada con exacta conciencia, es el mejor testimonio de nuestra personalidad. No sabremos quiénes somos ni nos daremos a conocer si esa misteriosa actividad no se ejerce y manifiesta. ${ }^{22}$

Este párrafo es de singular importancia por lo clarificador que puede resultar. Primero se recuerda que la poesía es un acto irracional en el que el poeta se deja llevar por su ánimo, por eso no será muchas veces consciente de lo que está escribiendo sobre sí mismo. Y es precisamente lo involuntario de la creación poética lo que la convierte en un acto tan sincero de plasmación de la personalidad, incluso de ciertas características irracionales ${ }^{23}$. Pero en este caso sólo el hombre que lleva a la práctica su voluntad poética, y no sólo el que recrea un objeto poético a través de la lectura, podrá beneficiarse del descubrimiento anímico que implica la poesía.

19.- «Todo poema -afirma Altolaguirre- puede ser considerado como un monólogo, cuando no supera csta condición y se hace diálogo. Soliloquio hay en que se multiplican las voces con los ecos de nuestros ángeles interiores, con los ecos también de quienes fuimos. Nuestro ayer dialoga con nuestro presente. Nuestros recuerdos contestan, dulce o amargamente, a nuestras esperanzas» ("Poesía dramática española", Las Españas (México), III, 8, abril 1949, pp.115. Cito por Obras Completas I, ed. cit., pp. 331-339, cita en p. 331).

20.- "En el campo de la poesía clásica española", art. cit., p. 277.

21.- "Sobre Nicolás Guillén” [1932], Obras Completas I, ed. cit., pp. 347-351, cita en p. 351.

22.- "En el campo de la poesía clásica española", art. cit., p. 277.

23.- "Poesía -afirma el poeta- es reciprocidad, comercio, amor, ya sea con Dios o con los hombres, ya sea con uno mismo, relación esta última de sobrecogedora angustia” (Ibídem, p. 277). 


\section{LA IDENTIDAD LITERARIA DE MANUEL ALTOLAGUIRRE}

1. 2. 3. 2. El segundo bien que aporta la poesía es el de incorporar a un mundo eterno la circunstancia pasajera del individuo:

[La poesía] sirve para rescatar el tiempo perdido, para levantar el ánimo, para tener alma completa, y no fugaces momentos de vida. En ella ensayamos la muerte, más que con el sueño. Ella nos libera de lo circunstancial, de lo transitorio. ${ }^{24}$

Los seres humanos están atrapados en una corriente temporal que los lleva a la muerte y en este limitado tiempo de vida pasan por diversas situaciones que al segundo se convicrten en pasado, en un recuerdo. Pero ya que las vidas pasajeras de todos los hombres son similares, hay una manera de unirlas para crear una línea permanente de experiencias situadas en un presente infinito. El instrumento de que el hombre se puede servir para inmortalizar su breve paso por el mundo en una corriente eterna es la poesía ${ }^{25}$ :

[...] Poemas que con un mismo acento se acercan y confunden misteriosamente, creando un maravilloso panorama con los sentimientos, los pensamientos y los sueños humanos. Tomar posesión de esos pensamientos, de esos sentimientos y de esos sueños poéticos es la más alta razón de nuestra existencia. Y cuanto más compenetremos nuestro transitorio sentir con esas permanentes creaciones del espíritu, mayor perfección daremos a nuestras vidas, tanto más enteras cuanto mayor sea el campo de nuestro conocimiento amoroso. ${ }^{26}$

Es decir, según Altolaguirre, la poesía ayuda a cumplir un objetivo vital para todo ser, al enseñarle a superar su mortalidad. Las personas crean a lo largo de su vida unos sentimientos, pensamientos y sueños de carácter estrictamente personal condenados a morir con ellos. Pero al elevar esas realidades individuales al mundo ideal de la poesía, se funden con los sentimientos, pensamientos y sueños de todos aquellos que han existido y existirán -puesto que la poesía es un continuum que no atiende a razones arbitrarias como el tiempo o el espacio-.

En resumen, la pocsía da al hombre la posibilidad de fundir su vida en un mundo colectivo y eterno, superando así la transitoriedad de su existencia y haciéndola más perfecta.

1. 2. 3. 3. El tercer aspecto manifiesta la positiva concepción que el malagueño tenía de las relaciones humanas pues alude a la capacidad de la poesía para unir a los seres en una fraternidad:

Ella [la poesía] nos hace unánimes, comunicativos. El verdadero poeta nunca es voluntario sino fatal. (No existen los poetas malditos). ${ }^{27}$

La poesía constituye un fuerte nexo de unión entre las personas porque, en el sentido de la creación, todos los seres humanos son similares en su innato don poético; y además, en el sentido de la recepción, todos tienen también la posibilidad de entender la poesía, aunque sea exteriormente. Por estos motivos, el hecho poético, gracias a lo que representa de natural y espontáneo, iguala a la humanidad y la mueve a la fraternidad.

24.- "Confesión estética", art. cit., p.154.

25.- Cuando Altolaguirre habla de la inmortalidad que logra el poeta al crear poesía no se refiere en ningún momento a la fama o reconocimiento público que un artista pueda conseguir. De hecho, para él, el trabajo del poeta es totalmente desinteresado y toda la fama que logre sólo redundará en beneficio de su pueblo y del arte mismo: «Hay literaturas que no cuentan con un verdadero poeta universal; siglos enteros en que la poesía vive en decadencia, y cuando, por el esfuerzo y desinterés de unos seres elegidos, la poesía alcanza un florecimiento, ha de pensarse que nada puede enriquecer la cultura humana como el auténtico lirismo, sin la cual no hay vida interior» ("Poesía y política", art. cit., p. 6).

26.- "En el campo de la poesía primitiva española", Universidad de la Habana, 43-45 (1942), pp. 42-47. Cito por Obras Completas I, ed. cit., pp. 270-275, cita en p. 271.

27.- "Confesión estética", art. cit., p. 154. 


\section{SUSANA ARROYO REDONDO}

Por otro lado, se debe recordar que para Altolaguirre la poesía es también una expresión amorosa. Y ya que el amor se puede explorar a través de los poemas, sería lógico que al crear o recrear esa poesía se avivaran los lazos de comunión entre los hombres:

Poesía: cosa cordial, que liga, que ata, que unifica a los hombres, que nos une también con lo que somos, con lo que fuimos, con lo que podamos ser; pues nuestros actos, nuestros pensamientos, no sólo toman cuerpo en la memoria de las gentes, sino que modelan y forman nuestros espíritus [...]. Espíritus que entran y salen de nosotros con la total sabiduría del hombre, con su total amor, que nos hacen semejantes, iguales en la felicidad. ${ }^{28}$

Los espíritus de los hombres, producto de sus experiencias vitales, les hacen unánimes en sabiduría y amor pues todos llevan una vida semejante. Por eso creía Manuel Altolaguirre que los hombres no sólo son iguales en la irracionalidad de su genio poético, sino que la vida también les va unificando a través de unos actos y de unos pensamientos que irán conformando unos espíritus similares. La poesía no sería más que una muestra de esa escondida fraternidad que une a los seres humanos, producto de la igualdad de sus almas.

1. 2. 3. 4. El último punto de la confesión estética que aquí se está empleando como clave para desvelar la identidad poética de Altolaguirre se refiere al alcance de los dones de la poesía:

La poesía salva no solamente al que la expresa, sino a todos cuantos la leen y recrean. Tiene más espíritu el buen lector que el buen escritor, porque el primero abarca mayores horizontes. Aún no he llegado a ser un buen lector de mi poesía. Aún no he logrado sentir todo lo que espero haber dicho. ${ }^{29}$

En este párrafo Altolaguirre elaboró una breve teoría de la recepción que vale la pena analizar. Según el malagueño el lector tiene la posibilidad de extraer líneas de pensamiento extremadamente vívidas de cualquier poema porque en esos versos reconocerá unos conocimientos o experiencias individuales que, al estar ahora sublimados por el lenguaje poético, lo ayudarán a entender el mundo y a sí mismo. Además, al igual que el cultivo de la poesía no depende de la voluntad ni de la razón, tampoco es necesario que el lector desee penetrar el misterio poético o sea un hombre culto porque cualquiera podrá al menos captar la belleza de un poema y beneficiarse de sus efectos.

En cambio, el autor muchas veces no percibirá todas las posibles vías de interpretación de su obra, pues el verdadero poeta escribe llevado por la irracionalidad. De hecho, para comprender todas las vías de conocimiento que su poema ha abierto, el escritor debe convertirse en lector de su propia obra.

\section{3. Historia de la poesía}

Manuel Altolaguirre escribió numerosos ensayos sobre poesía española, especialmente sobre la del Siglo de Oro y la del siglo XX, los periodos que a él más le interesaban. Aunque tiende a interpretar la obra de los demás de acuerdo a su propia estética, sus artículos también están llenos de comentarios muy agudos. Por ejemplo, fue uno de los primeros en señalar la influencia de

28.- "En el campo de la poesía clásica española", art. cit., p. 277. Esta idea del objeto poético como intento de fusión con los demás debe mucho a Vicente Aleixandre, a quien el malagueño consideraba públicamente como una figura fundamental en su formación literaria y humana (Poesía española contemporánea, ed. cit., p. 510) y quien también concebía la poesía como comunicación entre los hombres e incluso como «una forma de conocimiento amoroso» ("Poesía, comunicación", Obras completas II, Madrid, Aguilar, 1978, pp. 667-669, cita en p.669).

29.- "Confesión estética", art. cit,, p.154. 


\section{LA IDENTIDAD LITERARIA DE MANUEL ALTOLAGUIRRE}

Ramón Gómez de la Serna sobre el grupo del 27, en reclamar a Unamuno como poeta, a Azorín como dramaturgo y en ocuparse en España de la poesía de Nicolás Guillén ${ }^{30}$.

Sin embargo, a pesar de todos sus estudios sobre poesía española, y debido al alto grado de abstracción que caracteriza su visión poética, nunca quiso caer en la simplificación de trazar una historia de la literatura. Ya se ha precisado que para ćl la poesía es un ente natural y completo, cuya esencia es eterna a pesar de las variedades de su forma. Por esa razón nunca aceptó los estrictos cánones de aquellos filólogos que encorsetan la literatura en perodos históricos cerrados y definen cada tendencia por oposición a las demás, sin dejar margen a influencias o vacilaciones.

Para el poeta malagueño era imposible pensar en una historia diacrónica de la poesía; incluso hablar de su presente sería falso. Según su concepción, toda la poesía escrita a lo largo de la historia formaría un continuum uniforme en el que la fecha de creación no tiene ninguna importancia:

No pretendo hacer una historia de la poesía, ni debićramos hablar, del tiempo al referirnos a ella, a su presente. Debiéramos hablar de ella, y así quiero presentárosla, como un hermoso cuadro. Quiero hablaros del campo de la poesía, de su infinito espacio poético, en donde las distancias son ajenas a toda idea de muerte y en donde las criaturas poéticas están unidas entre sí por razones de verdadera vida, cercanías que prescinden de fechas y autores. ${ }^{31}$

Efectivamente, Altolaguirre concebía el universo poético como un estadio de sabiduría superior al que accedían los hombres al crear o recrear la poesía y en el que no tendría sentido establecer barreras caprichosas entre los poemas, porque las fechas de composición o el nombre del escritor son arbitrariedades que nada tienen que ver con la sustancia poética. Lo único importante es el sentimiento desencadenado por esa obra.

Todas estas ideas quedaron bien reflejadas en los últimos versos del siguiente poema que reflexionan sobre la naturaleza de la poesía, "A veces las más tristes":
$\Lambda$ veces las más tristes realidades
no llegan por mis ojos a mi alma,
ni devastan con llantos y tormentas
las tierras interiores de mi sueño.
No me dejo apresar por lo aparente,
lo transitorio de esta vida;
sólo una brisa breve me propaga.
No soy cruel, amigos. Conocedme.
Lo inhumano en mí es que no muero. ${ }^{32}$

En los primeros versos se explica primero cómo el poeta posee un modo de conocimiento inagotable que no proviene de los sentidos, sino de su acceso al mundo poćtico. En la segunda parte la poesía toma cuerpo en el poeta y habla por su boca para explicar su divina naturaleza; la propia poesía invita al lector a sumergirse en clla, en su cauce infinito. Y ya en el extraordinario y último verso se revela la auténtica naturaleza del hecho poćtico: que las criaturas poéticas carecen de principio y de fin porque no tienen pasado ni futuro, sólo un eterno presente.

\footnotetext{
30.- A este respecto, hay ciertos artículos del malagueño que merecen absolutamente ser rescatados del olvido, por ejemplo, "Nuestro teatro" (Hora de España (Valencia), 9, septiembre 1937, pp. 29-37), donde traza una certera reflexión sobre la situación del arte escénico español y su futuro; "Don Miguel de Unamuno" (Revista hispánica moderna (Nueva York), VI, 1, enero 1940, pp. 17-24), donde trata de acercarse a la compleja figura del filósofo; "Vida y Poesía: cuatro poetas íntimos" (Lyceum (La Habana), IV, 14, 1939, pp. 15-29), donde repasa la obra de Prados, Cernuda, Aleixandre y Concha Méndez, que acaba por convertirse en un póstumo homenaje a Lorca.

31.- "En el campo de la poesía primitiva española", art. cit., pp. 270-271.

32.- Extraído de "Nuevos poemas a Las Islas Invitadas" [1936], Poesías completas, ed. cit., p. 236.
} 


\section{SUSANA ARROYO REDONDO}

Sin embargo, por más que su concepto de poesía fuese demasiado etéreo como para poder someterlo a clasificación alguna, Altolaguirre trabajó también como profesor y no pudo negar a sus alumnos la posibilidad de conocer el desarrollo histórico de la literatura. En consecuencia, llegó a admitir que, aun no pudiéndose sistematizar la poesía, sí era posible ordenar históricamente el cauce que la contiene: el lenguaje.

Pero si la poesía, por ser de alma, carece de historia, no le ocurre lo mismo con su cuerpo, que es el idioma, que como todo río o vida, termina dando en la mar, que es el morir. Debemos pues dibujar en ese campo poético de que hemos hablado largos ríos de palabras, para tener delante, con antiguas y modernas corrientes, esa gracia indecible, esa clarísima actualidad o eternidad de la poesía. ${ }^{33}$

Y gracias a esta bella metáfora de la poesía como un prado surcado por distintos ríos de palabras, Altolaguirre puede dibujar un sucinto recorrido por la historia de la poesía española en el que nunca profundizará demasiado en las clasificaciones y jamás impondrá límites precisos a cada uno de los periodos considerados.

Estas cuatro grandes y difusas etapas de la poesía española serían las siguientes:

- Poesía primitiva: «es esencialmente descriptiva, exterior, impersonal, de coro, o de soledad con eco».

- Poesía clásica: «es la que tiene su raíz en el pensamiento y cuyo acento está medido con un rigor de norma, bajo unas leyes voluntarias de recreación íntima».

- Poesía romántica: «corresponde al mundo de los sentimientos, con la libertad que la pasión desordenada propicia».

- Poesía moderna: «sobre la realidad primitiva, sobre el pensamiento clásico, sobre la pasión romántica, coloca la involuntaria y misteriosa intimidad de los sueños, poesía en la que el poeta revela su verdadera vida, la secreta complejidad de su entrañable naturaleza». ${ }^{34}$

El malagueño resume la extensa historia de la poesía española en apenas cuatro movimientos acertadamente descritos donde lo que le importa destacar es el recorrido hacia lo interno que ha sufrido esta arte a través de los siglos: desde la poesía más descriptiva hasta la que recorre la última capa de la personalidad, lo inconsciente. De este modo, la historia de la poesía sería un viaje de exploración cuyo objetivo consistiría en adentrarse en los misterios del alma humana ${ }^{35}$.

A modo de conclusión de este apartado, se ha de señalar que Altolaguirre usó esta brevísima descripción de la historia de la poesía con un fin docente. Pero en cualquiera de sus críticas literarias se puede ver que este poeta se sentía muy libre de mezclar terminologías de épocas diferentes y comparar autores de periodos diferentes -así estima que ciertos versos de Juan de Mena poseen un «acento modernista, casi verleniano» ${ }^{36}$.

33.- "En el campo de la poesía primitiva española", art. cit., p. 272.

34.- Ibídem, p. 272.

35.- Por otra parte, Altolaguirre destacó la figura de un creador representativo de cada periodo. Entre los autores primitivos, siempre reconoció la influencia que sobre él había ejercido Jorge Manrique. Respecto a los clásicos, admiró a Garcilaso y Luis de Góngora. De los románticos prefirió a Bécquer. Sobre sus contemporáneos, los poetas modernos, señaló que su poesía se sentía hermana menor de la de Pedro Salinas, y también que Emilio Prados, Vicente Aleixandre y Luis Cernuda influyeron personalmente en su formación literaria ("Poética", Poesía española contemporánea, ed. cit., p. 509).

36.- "En el campo de la poesía primitiva española", art. cit., p. 273. 


\section{LA IDENTIDAD LITERARIA DE MANUEL ALTOLAGUIRRE}

Pero acusarlo de falta de rigor sería injusto; para entender la crítica literaria de Altolaguirre se debe primero comprender su identidad poética. Si se tiene en cuenta que para él la poesía es un continuum en el que no se pueden establecer fechas ni nombres porque sólo importa la verdad del poema, se comprenderá que Altolaguirre se sintiera libre de relacionar autores tan dispares. De hecho, parece que su desdén por las férreas estructuras que la crítica literaria se había impuesto a sí misma le dio una visión mucho más sincera y humana de ese prado infinito que es la poesía.

\section{Poeta}

Siguiendo las líneas trazadas para la definición de la poesía, Altolaguirre habló en un segundo término de la figura y de la labor del poeta. Como ya se habrá podido percibir en las páginas anteriores, el malagueño concedía a la poesía una importancia absoluta, unos poderes ilimitados. Por el contrario, el poeta no es un ser extraordinario; de hecho, todo hombre nacería con una innata capacidad poética, sólo comparable a su capacidad amatoria. En este sentido, señaló que esforzarse por buscar la verdadera poesía no sirve de nada ya que es ella la que acude al encuentro del individuo; la condición de poeta es meramente casual. Así, frente al poderoso concepto de la poesía, el poeta ocuparía un lugar secundario en la teoría del malagueño ya que poco puede hacer el hombre que quiera encontrar la verdadera poesía, sólo tratar de depurar su palabra.

\section{1. Poeta}

Retomando la vieja disputa ars/natura, se puede decir que Manuel Altolaguirre consideraba que el poeta nace con un don natural y que no necesita ningún estudio de retórica o preceptiva para perfeccionar su obra. Al igual que todos los hombres nacen con la capacidad de amar, todos nacen capacitados para crear poesía. El poeta será aquel hombre que se deje llevar por la irracionalidad y consiga convertir su deseo de crear en una firme realidad.

Si la poesía es involuntaria e irracional, una expresión connatural al hombre, es lógico que no se puedan establecer diferencias entre la poesía de los poetas profesionales y la de un aficionado, pues ambas son expresiones iguales con matices diferentes:

\footnotetext{
La poesía intencional de los poetas cultos y la pocsía involuntaria de los demás hombres es una misma $\cos ^{3} .^{37}$
}

Por tanto, el camino para encontrar la poesía no es la brillantez formal o el hermetismo. De hecho, en ninguno de sus artículos de crítica literaria señaló nunca una normativa formal a seguir, únicamente anotó que prefería la sencillez y la claridad en los versos. Los hombres que quieran convertirse en poctas no deben seguir ninguna consigna estética o social determinada, ni buscar la erudición, sólo trabajar para depurar la expresión de sus sueños, pensamientos e ideas ${ }^{38}$.

Por otra parte, el otro requisito indispensable para un poeta sería una capacidad extraordinaria para amar la vida:

El poeta, como todo enamorado, tiene que mirar con buenos ojos a la vida, que es la mejor musa, y con la que, al fin y al cabo, realizará su obra. ${ }^{39}$

37.- "Enseñanzas de Garcilaso", art. cit., p. 174.

38.- Esta romántica concepción del genio poético dotaba a Altolaguirre de una sensibilidad especial para apreciar la poesía popular. De hecho, en uno de sus artículos relata cómo se acercó hasta las expresiones más básicas y sinceras de los poetas callejeros, descubriendo lo que ahora se conoce como "literatura efímera": «Hoy cerré los libros de mis poetas [...] para ir a buscar la poesía en medio de la calle. [...] Muchas veces, desde la ventanilla de un tranvía o ante los cristales de mi taxi, he visto aparecer tales leyendas, tan rápidas, tan fugaces, que sólo me dejaron en la memoria un ligero sabor de poesía. [...] Un muchacho ha pasado ante mí llevando su camión a toda marcha. Lo que llevaba escrito en el parabrisa se le leía en el rostro. En letra roja, grande, sobre el esmalte gris, decía su sangre: "Soy el amor de Gloria". [...] No de otra forma iría con su estandarte un Amadís de Gaula en busca de aventuras» ("Versos en los camiones", Excélsior (México), 18-diciembre-1948, pp. 6-14. Cito por Obras Completas I, ed. cit., pp. 183-185). 39.- "Poética", Poesía española contemporánea, ed. cit., p. 509. 


\section{SUSANA ARROYO REDONDO}

Es decir, el poeta debe manifestar una predisposición a amar todo lo que le rodea porque la poesía es amor. Sólo aquel hombre con suficiente capacidad para enamorarse del mundo podrá asimilarlo hasta que la acumulación de experiencias haga salir de su pluma un objeto poético valioso.

Si la poesía es amor, el poeta debe ser un enamorado y la vida su amada. Sólo entonces, una vez que depure su verso y se haya enamorado del mundo, ese hombre que ha nacido con el mismo don poético que los demás se convertirá en un artista de calidad:

El poeta virtuoso de su arte, el que alcanza en la expresión de ideas y sentimientos la máxima calidad, estará siempre sometido a su inspiración y a su conciencia, con absoluta confianza en sus facultades, que por excepcionales y privativas pueden ser incomprendidas por el vulgo, aunque el premio mayor que puedan merecer sea la consagración popular. ${ }^{40}$

Este fragmento introduce dos temas muy interesantes; por un lado, la incapacidad de las masas para comprender $\mathrm{el}$ arte; por otro, la idea de que el máximo honor al que puede aspirar un poeta es la asunción de su obra por el pucblo. Es decir, a pesar de que Altolaguirre concebía al poeta como un hombre con una sensibilidad especial alejado de las masas, no siguió las doctrinas críticas que Ortega y Gasset había puesto tan de moda en La deshumanización del arte (1925). El verdadero poeta sería un hombre con una clara función social, un guía para su pueblo, aunque su poesía no transmitiera ideas colectivas.

Y para convertirse en un poeta de calidad - sin necesitar erudición- y ser un poeta del pueblo -sin hacer propagandas políticas-, sólo hay un camino. El verdadero poeta, como hombre enamorado de la realidad, la asumirá hasta formar un nuevo mundo en su interior; sólo entonces brotará de él la palabra poética y creará un nuevo mundo.

El saber darle una interpretación personal a las cosas, creando nuevas realidades en ellas, es un intento admirable que nos llevará sin duda a la consecuencia de una nueva estética, estética tanto más interesante cuanto que sería comprendida por nosotros, sería llegada a nuestra sensibilidad no por el camino fisiológico de los cinco sentidos corporales sino por lo que pudiéramos llamar sentido poético, atributo anímico, cualidad de verdadero artista."

Este "sentido poético" permitiría a los poetas comprender el mundo gracias al filtro del objeto artístico. En definitiva, el objetivo del verdadero poeta consistiría en crear un nuevo mundo estético que capte a la perfección la sensibilidad humana.

\section{2. Pertenencia a un grupo}

Entre los beneficios de la producción y lectura de poesía, Altolaguirre destaca su poder para hermanar a los hombres. La poesía «nos hace unánimes y comunicativos» ${ }^{42}$, es un importante nexo de unión entre todos los humanos gracias a la similitud de su genio poético y a su capacidad irracional para crear arte.

Pero si esta capacidad fraternal de la poesía se manifiesta ya en hombres corrientes, lo hará con mucha más fuerza entre los poetas. Así en 1940 escribía unas líneas que muestran su voluntad de pertenencia a un grupo poético:

$\mathrm{Y}$ es que el pocta que se entrega al conocimiento de los otros autores lo hace siempre por un afán de coincidencia, con un propósito de definición. No hay fraternidad como la de los poetas. Todos son hermanos con la misma hermosa sangre. ${ }^{43}$

40.- "Poesía y Política", art. cit., p.6.

41.- De Altolaguirre a Gerardo Diego. Epistolario, Madrid, Caballo griego para la poesía, 1991. Epístola del 17-6-

25 sobre el libro Imagen.

42.- "Confesión estética", art. cit., p. 154.

43.- "Enseñanzas de Garcilaso", art. cit., p. 174. 


\section{LA IDENTIDAD LITERARIA DE MANUEL ALTOLAGUIRRE}

Este afán de coincidencia con otros poetas se puede entender en un sentido diacrónico, pero también sincrónico. Es decir, el poeta no sólo debe buscar identificarse con los clásicos, sino también con sus contemporáneos. De este modo, Altolaguirre se manifiesta completamente a favor de la socialización del poeta, de su integración en un grupo poético que lo ayude a desarrollar su arte a través de ciertas consignas comunes.

No hay que olvidar que el malagueño vivió su juventud en la estrecha amistad de numerosos poetas y artistas con los que compartió inquietudes artísticas y preocupaciones políticas. De ahí su confianza en la hermandad de los poetas como grupo de hombres especialmente influidos por el amor que exige y otorga la creación artística.

Sin embargo, después del exilio y de la muerte de muchos de sus compañeros de su generación, Altolaguirre, aunque nunca dejó de confiar en los beneficios de integrarse en un grupo poético, comprendió el vacío en que quedaba el poeta cuando ese grupo se rompía:

El poeta no se da nunca exacta cuenta de cuando deja de ser joven para convertirse en un superviviente. Encerrado o formando parte de un anillo literario, cuando éste se deshace, de repente se encuentra flotando a la deriva o arribando a la playa de una isla desierta, [...] Villalón, Miguel Hernández, Federico García Lorca, Moreno Villa, Vallejo, Pedro Salinas... cuyas voces repaso de continuo, nombres y sombras son que me hacen ser un superviviente. Se diría que al dejarlos atrás ya no tiene sentido para mí el seguir escribiendo, porque hay voces en las que cuenta tanto la raíz como el destino. ${ }^{4}$

En estas líneas se puede leer la amargura de Altolaguirre veinte años después de escribir la cita que abría este apartado. Pero su tristeza no revela sólo su pena por la muerte de ciertos compañeros sino el aislamiento en que quedó sumido tras la división del grupo, su desilusión al no poder disfrutar más de esa fraternidad de poetas.

\section{3. Compromiso político}

Altolaguirre fue un poeta extremadamente comprometido con su época, de hecho, durante la guerra contribuyó a crear varias revistas -como Los Lumes de El Combatiente o Granada de las letras y de las armas - con el objetivo de que no se malograra la cultura española durante aquellos aciagos años; y tras la guerra hubo de exiliarse primero a Francia y luego a Hispanoamérica a causa de su continua colaboración con el bando republicano.

Pero a pesar de su compromiso como hombre, como poeta juzgó siempre que lo social no debe mezclarse con la poesía sino mantener su absoluta independencia ${ }^{45}$. Es decir, nunca creyó en el proselitismo literario; siempre fue fiel a su poesía íntima y jamás aconsejó crear una poesía "social" que cayera en lo simple o rebajara su dificultad para hacerse asequible a cualquiera:

El que la poesía en su más luminosa manifestación sea gozada por un reducido número de lectores no es culpa del poeta, que al serlo auténticamente, no hace depender lo que escribe de circunstancias ni de efectos exteriores. ${ }^{46}$

Puede que esta actitud de despreocupación hacia los receptores parezca una contradicción en la identidad poética de un hombre tan comprometido con el pueblo. La clave para deshacer este misterio consiste en recordar la confianza absoluta que el malagueño tenía en el ser humano. Como ya ha sido expuesto, Altolaguirre creía que todos los hombres son iguales para la creación y recreación poética, por tanto, a nadie le está vedada una mínima comprensión tras la lectura de un poema:

44.- "Juventud y compromiso" [1957], Poesías completas, México D. F., Fondo de Cultura Económica, 1960, pp. $10-11$.

45.- Con esta sutileza consiguió evitar las contradicciones que para él supusieron la guerra: durante los primeros días del conflicto perdió a su hermano lederico, fusilado por los republicanos; luego su amigo Federico García Lorca fue asesinado por el bando fascista; y finalmente su otro hermano Luis fue fusilado también por republicanos. Puede que al separar su mundo poético de lo social consiguiera hallar un reducto de paz en medio de la convulsa situación política.

46.- "Poesía y política", art. cit., p. 6. 


\section{SUSANA ARROYO REDONDO}

En esta hoja [Los lunes de El Combatiente ] irán apareciendo poemas, prosas, críticas, nunca demasiado complicados o incomprensibles, pero tampoco fabricados con la preocupación de ser demasiado fáciles. Porque, como ya tiene dicho uno de nuestros más grandes poetas, no importa que un poema, que una obra de creación, no entregue totalmente su misterio; basta, sí, con que el espectador de esa obra sienta el roce de su belleza y hondura. ${ }^{47}$

Hay que recordar que, tras la muerte de Lorca, Altolaguirre se ocupó de la dirección de "La Barraca". Esta compañía teatral dio a conocer a los mejores clásicos a muchos españoles iletrados, pero sin reducir la dificultad del texto, porque tanto Federico como Manuel confiaban de modo pleno en la universalidad de la belleza, asequible intuitivamente para todo hombre. Nunca se consideraron maestros de un pueblo inculto, al contrario, confiaron en la sabiduría popular como fuente de conocimiento e incluso como cauce poético ${ }^{48}$.

Por tanto, el poeta no debe dejarse influir por los acontecimientos exteriores sino seguir su propio destino poético, que lo llevará por los caminos de lo popular, la infancia y el sueño. Si un poeta sacrifica su arte en aras de una consigna exterior, nunca realizará plenamente su obra. Además, tampoco es necesaria esta renuncia para llegar al pueblo, pues si el poeta es sincero en sus versos, se produce una reciprocidad con el lector. En definitiva, su compromiso no es con un determinado grupo político, sino con su propia poesía:

No debe contentarse sólo con seguir las consignas que considere justas, ni las causas que estime como nobles; porque al hacer esto, logrará pertenecer a un coro honroso, propagandista y eficiente, pero permanecerá en la oscuridad del anonimato, por más que su firma calce ideas colectivas y benéficas. El poeta tiene que superar esa adhesión a unas ideas humanitarias y justas. Tiene que cumplir su destino poético, ${ }^{99}$

Hay que tener en cuenta que estas afirmaciones no fueron hechas por un joven y frívolo intelectual, sino que son declaraciones efectuadas en 1949 por un Altolaguirre que ya había vivido una guerra, una derrota y un exilio. De hecho, el poeta había mantenido esta misma posición durante el conflicto español, época en la que tanto se cuestionó el papel del intelectual en los conflictos sociales ${ }^{50}$.

Por otra parte, también señaló Altolaguirre que aunque el compromiso del poeta no le obliga a redimir el mundo, si decide embarcarse en la tarea de socorrer o recuperar la literatura, también esa labor resultará baldía. Ciertamente, la literatura no necesita ser salvada porque no puede desaparecer; es una realidad inevitable que no puede guardarse o protegerse:

[EI arte] es algo que tiene una existencia fatal e irremediable [...]. Nadie tiene el derecho a creer, respecto a la literatura, que sea una cosa conveniente o inoportuna, dañina o salvadora. Fs, y nada más. Y cuando algo tiene esa vida, esa fuerza, ese poderío, quiere decir que se trata de algo natural y $\operatorname{completo}^{51}$

47.- "Editorial", Los lunes de El combatiente, 1, (14- octubre-1938). Cito por Obras Completas I, ed. cit., pp. 407408 , cita en p. 407.

48.- En este sentido, Altolaguirre se complacía en contar una anécdota sobre la representación de su comedia $L a$ Estrella de Valencia: "En uno de sus cuadros inserté unos preciosos versos que no eran míos [...] Y el público se emocionaba, noche a noche, con esos versos admirables. Pero la crítica, por la pluma de un erudito que naturalmente ignoraba que tales versos fueran de Cervantes, me dijo: “Cómo pudo escribir usted, tan buen poeta, unos versos tan malos?"” ("Don Miguel de Cervantes", Obras Completas I, ed, cit., pp. 304-309, cita en pp. 305, 306).

49.- "Poesía y Política", art. cit., p. 6.

50.- Pero al acabar la guerra, mientras huía a Francia con su familia, cayó en una profunda depresión al considerarse responsable de la derrota republicana: creía que no había animado lo suficiente a las tropas a seguir luchando. Sin embargo, diez años después de la guerra, una vez superado su complejo de culpa, volvió a su antigua tesis de que el poeta debe mantener apartado lo social de su poesía, la cual debe desarrollarse por cauces estrictamente individuales. 51.- "Editorial", ed. cit., p. 407. De nuevo en estas declaraciones se hace evidente la influencia de sus maestros José Ortega y Gasset, quien fue uno de los mayores promotores de la concepción del arte por el arte, y Juan Ramón Jiménez, que defendió la independencia de la poesía en unos términos idénticos a los de Altolaguirre: "La poesía escrita, como las otras artes de creación, siempre es natural, por perfecta que sea; o mejor, es perfecta, completa porque es natural" ("Poesía y L.iteratura", Antolojía, ed. cit., p. 284). 


\title{
LA IDENTIDAD LITERARIA DE MANUEL ALTOLAGUIRRE
}

Mientras que la literatura no necesita al hombre, éste sí depende de ella para conocer lo que sabía y ha olvidado, para eternizar sus efímeros momentos de vida, para unirse a los demás.

Por último, a fin de ilustrar el tema del compromiso político en la poesía de Altolaguirre, se incluye a continuación uno de los poemas que dedicó a la angustia de la guerra. En él se describe cómo los horrores de la contienda nunca lo hicieron desviarse de su destino poético aunque sí llegaron a alterar profundamente su voz lírica:

\author{
Entre alaridos se sostiene \\ su débil rama, \\ entre escombros de guerra, \\ viva en mi corazón endurecido, \\ como una flor sencilla \\ entre las piedras del pasado, \\ está mi voz primera, \\ la inocente palabra de mis versos, \\ esperando que se retiren los fantasmas, \\ se ordenen los quebrados edificios, \\ se cierren las trincheras. $[\ldots]$ \\ Es la guerra, mi voz acostumbrada \\ a cantar al amor y el pensamiento, \\ llora esta ve\% el odio y la locura. \\ Fuera de sí mi voz llora el ardiente \\ delirio de un incendio apasionado, \\ llora su rojo fuego vengativo. ${ }^{52}$
}

El humanismo de Manuel Altolaguirre le impidió dejar su voz poética al margen de los acontecimientos históricos, sin embargo afrontó esta intromisión desde un punto de vista muy particular. Se podría pensar que a pesar de lo que opinara como crítico, en ese momento, como poeta, se sentía casi incapaz de seguir su destino poćtico y cedió a cierto desconsuelo. Aún así, el malagueño no describe en sus versos la terrible situación de España tras el segundo año de guerra, sino que se centra en los efectos que esa desgracia ha tendido sobre su poesía. El poeta ha observado su mundo, lo ha interiorizado y ha creado una estructura de palabras que refleja su particular visión de lo real.

\section{Conclusiones}

Oscurecida durante mucho tiempo por la sombra de sus compañeros de generación, la teoría poética de Manuel Altolaguirre merece ser recuperada no sólo porque esclarece la identidad literaria del poeta malagueño sino porque ofrece un original accrcamiento al universo poético del grupo del 27.

En primer lugar, destaca la importancia capital que Altolaguirre otorga a la poesía frente al papel subordinado del poeta; mientras aquélla se presenta como una potencia eterna y autosuficiente, éste es apenas el canalizador inconsciente de una fuerza superior, un hombre elegido al azar por el dedo caprichoso de la diosa poesía. Este neorromanticismo contrasta vivamente con la actitud más deshumanizada de sus compañeros de generación, quienes vincularon el éxito del proceso creador a los esfucrzos conscientes del artista.

Otro punto que merece ser apreciado en la teoría poética del malagueño es la delicadeza con que concibe la naturaleza de la sustancia poética, que sólo sería comparable al amor mismo ya que

52." "Mi voz primera", extraído de "Nube temporal" [1939], Poesías Completas, ed. cit., pp. 262-264. 


\section{SUSANA ARROYO REDONDO}

son dos capacidades innatas que se manifiestan por igual en todos los hombres aunque con infinitos matices. Es precisamente esta cualidad amorosa de la poesía la que la convierte en un artefacto de unión en varios sentidos: fusión del mundo exterior y de la intimidad del poeta, reencuentro de los hombres en fraternidad y hallazgo de un mundo en que recuperar conocimientos ya olvidados.

Por otra parte, es importante resaltar lo que no existe en la teoría crítica de Altolaguirre: una preceptiva formal. Jamás trató de reducir la complejidad de la creación estética a un determinado número de versos o sílabas, sólo aconsejó la sencillez y la sinceridad, así como ciertas limitaciones temáticas. En efecto, el artista sólo encontraría la verdadera poesía al inspirarse en los sueños, la infancia o su propia personalidad. Por el contrario, rechaza toda intromisión de asuntos políticos o sociales, ya que apartarían al poeta de su verdadero destino.

Por último, se puede señalar la fuerte coherencia del pensamiento crítico de Altolaguirre. Su sólida teoría se asienta sobre unos pocos pero firmes conceptos alrededor de los que teje una red de ideas autorreferenciales. Además, su pensamiento también fue estable en el tiempo, a lo largo de su vida mantuvo una actitud devota hacia la poesía y no varió los principios de su teoría crítica.

En conclusión, puede que el hecho de que el malagueño no escribiera nunca una obra extensa sobre su concepción poética y de que sus artículos fueran publicados en revistas de difícil acceso haya impedido hasta ahora conocer sus interesantes reflexiones, pero la originalidad del pensamiento profundamente humano de Altolaguirre, además de la cohesión de sus ideas con las de los otros miembros de su generación, hacen de su teoría poética un objeto interesante por sí misma y por su valor para adentrarse en el conocimiento del grupo del 27. 